\title{
Targeted expression of tumor necrosis factor- related apoptosis-inducing ligand TRAIL in skin protects mice against chemical carcinogenesis
}

\author{
Valerie Kedinger, Stephanie Muller and Hinrich Gronemeyer ${ }^{*}$
}

\begin{abstract}
Background: Gene ablation studies have revealed that tumor necrosis factor-related apoptosis-inducing ligand (TRAIL, Apo2L, TNFSF10) plays a crucial role in tumor surveillance, as TRAlL-deficient mice exhibit an increased sensitivity to different types of tumorigenesis. In contrast, possible tumor-protective effect of increased levels of endogenous TRAIL expression in vivo has not been assessed yet. Such models will provide important information about the efficacy of TRAIL-based therapies and potential toxicity in specific tissues.
\end{abstract}

Methods: To this aim, we engineered transgenic mice selectively expressing TRAIL in the skin and subjected these mice to a two-step chemical carcinogenesis protocol that generated benign and preneoplastic lesions. We were therefore able to study the effect of increased TRAIL expression at the early steps of skin tumorigenesis.

Results: Our results showed a delay of tumor appearance in TRAIL expressing mice compared to their wild-type littermates. More importantly, the number of tumors observed in transgenic animals was significantly lower than in the control animals, and the lesions observed were mostly benign. Interestingly, Wnt/ $\beta$-catenin signaling differed between tumors of wild-type and TRAlL transgenics.

Conclusion: Altogether, these data reveal that, at least in this model, TRAlL is able on its own to act on pretransformed cells, and reduce their tumorigenic potential.

\section{Background}

Tumor necrosis factor-related apoptosis-inducing ligand (TRAIL, Apo2L, TNFSF10), a type II trans-membrane death ligand, has the unique property of inducing apoptosis in tumor cells while sparing normal ones [1]. The human protein shares $65 \%$ amino-acids identity with its murine counterpart [2]. TRAIL forms homotrimers that ligate to two types of receptors: death receptors that trigger TRAIL-induced apoptosis and decoy receptors that can antagonize apoptosis induction. In humans, two death receptors (DR4/TRAIL-R1/TNFRSF10A and DR5/ TRAIL-R2/TNFRSF10B) [3,4] and two decoy receptors (DcR1/TRAIL-R3/TNFRSF10C and DcR2/TRAIL-R4/ TNFRSF10D) [5] have been identified. In mice two decoy receptors ( $\mathrm{mDcR} 1$ and $\mathrm{mDcR} 2$ ) have been characterized [6] but only one death-inducing receptor (mDR5,

\footnotetext{
* Correspondence: hg@igbmc.fr

Department of Cancer Biology, Institut Génétique de Biologie Moléculaire et Cellulaire (IGBMC), BP 10142, 67404 Illkirch-Cedex, C.U. de Strasbourg, France
}

mTRAILR2) that shares sequence homology with both human DR4 and DR5 was found [7].

Binding of TRAIL to one of the death receptors results in receptor oligomerization and recruitment of the FAS-associated protein with death domain (FADD), which itself recruits membrane proximal caspases (caspase 8 and 10). The resulting protein complex has autocatalytic activity and is designated as the death-inducing signaling complex (DISC). The activation of this complex induces activation of a caspase cascade, which cleaves numerous proteins and ultimately leads to cell death [[8] and references therein].

Increasing evidence from various types of experimental models supports the notion that TRAIL can affect tumor onset and development. Indeed, tumor transplantation experiments with TRAIL- and TRAILR-deficient mice and the use of TRAIL-neutralizing antibodies revealed that endogenous TRAIL expressed in NK cells contributes to host immunosurveillance against primary tumors and metastases. Moreover, TRAIL exerts a 
potent tumoricidal activity in cancer cells in vitro and in vivo, causing negligible effects on normal cells when exogenously administered, an important feature of this cascade regarding its therapeutic potential [9-25]. Therefore, recombinant TRAIL, TRAIL "mimics" [26] and agonistic TRAIL receptor antibodies are attractive potential tools for anticancer therapy.

While loss-of-function studies have provided important information revealing accelerated tumor formation in TRAIL-deficient mice and thereby confirmed its implication in tumor defense, the corresponding in vivo gain-of-function analysis demonstrating protection against tumorigenesis by increasing endogenous TRAIL levels in the animal or a given tissue has not yet been done. Irrespective of the information that can be obtained with recombinant TRAIL, which corresponds only to a part of TNFSF10, TRAIL mimics or with agonistic TRAIL receptor antibodies, an understanding of the impact of increasing cellular TRAIL levels is an essential aspect of its biological function. Moreover, with this approach, cell and tumor-type efficacies including possible adverse effects of TRAIL therapies can be assessed, as well as the toxicity of increased levels of endogenous TRAIL in vivo, including effects on early development. Note that not only tumoricidal, but also increased proliferation upon exposure to recombinant TRAIL has been reported in some cases of human cancer [27] and inflammation models [28]. Finally, only in vivo models in which TRAIL is overexpressed in selected tissues will reveal at which stage of tumor development TRAIL overexpression becomes tumorprotective or tumoricidal, and which cell types (premalignant or malignant cells, tumor proximal normal cells, cells of the immune system) contribute. To this aim we have initiated a study in which the effect of TRAIL overexpression in the skin on chemically induced epithelial tumorigenesis was assessed.

For this we took advantage of the well-established 7,12-dimethyl-benz-anthracene/12-0-tetradecanoylphorbol-13-acetate (DMBA/TPA) two-stage skin carcinogenesis model. This tumor induction protocol recapitulates comprehensively the multistage nature of human epithelial cancer development [29], as it first gives rise to benign neoplastic lesions (papillomas) from which a small percentage progress into malignant squamous cell carcinomas (SCCs). In most strains of mice however, progression of benign papillomas into SCCs is a rare and late event. Ultimately, a small fraction of these tumors can metastasize to distant organs. To study the protective effect of increased endogenous TRAIL levels we engineered mice to specifically overexpress TRAIL in the skin and subjected these mice to the two-step chemical carcinogenesis protocol.

\section{Methods}

\section{Generation of transgenic mice}

To selectively induce expression of TRAIL in the skin, a construct was generated in which the mouse TRAIL cDNA was placed under the control of the human keratin 14 (K14) promoter. To allow a more efficient expression of the transgene, an intron of the $\beta$-globin gene, flanked on both sides by small parts of the exons 1 and 2 , respectively, was introduced between the K14 promoter and the mTRAIL cDNA. The SV40 3'UTR was added at the end of the construct. This construct was microinjected into the male pronucleus of a fertilized mouse oocyte, which was than transplanted into a pseudo-pregnant recipient female.

\section{Carcinogenesis}

The mice were housed in a temperature-controlled room with $12 \mathrm{~h}$ cycles of light and dark. 8 to 10 weeks old wild type and TRAIL transgenic mice were shaved to synchronize the hair cycle and treated the day after with a single dose of $50 \mu \mathrm{g}$ DMBA (7,12-dimethyl-benzanthracene) (Sigma, St Louis, MO, USA) in $100 \mu \mathrm{l}$ acetone. One week after DMBA application, $5 \mu \mathrm{g}$ TPA (12-O-tetradecanoyl-phorbol-13 acetate) (Sigma) in $200 \mu \mathrm{l}$ acetone was applied topically twice a week for 35 weeks. Control mice received acetone only. The number of tumors per mouse was weekly recorded and their size was measured with a Vernier calliper.

\section{In situ Hybridization}

Skin samples from wild-type and TRAIL transgenic mice were collected, fixed overnight in $4 \%$ formaldehyde and embedded into paraffin. The paraffin sections were first rehydrated and primed with proteinase $\mathrm{K}$, followed by dehydratation through graded ethanols. Pre-treated sections were covered with $150 \mu$ l hybridization buffer (50\% formamide, $10 \%$ dextran sulfate, $1 \times$ Denhart's solution, $10 \mathrm{mM}$ Tris- $\mathrm{HCl} \mathrm{pH} 7.5,600 \mathrm{mM} \mathrm{NaCl}$, $1 \mathrm{mM}$ EDTA, $0.25 \%$ SDS, $0.5 \mathrm{mg} / \mathrm{ml}$ yeast tRNA) containing $100 \mathrm{ng} / \mathrm{ml}$ of DIG-labeled RNA probe, and hybridized at $55^{\circ} \mathrm{C}$ overnight. After hybridization, slides were washed twice with $2 \times$ SSC, followed by $0.2 \times$ SSC once at $45^{\circ} \mathrm{C}$ to remove unbound probe. The sections were then incubated with Blocking buffer (0.1 M Tris$\mathrm{HCl} \mathrm{pH} 7.5,0.15 \mathrm{M} \mathrm{NaCl}$, saturated with block reagent) for $1 \mathrm{~h}$ at room temperature. Alkaline phosphataseconjugated anti-DIG antibody was diluted in blocking buffer and incubated on slides for $2 \mathrm{~h}$ at room temperature. Sections were then rinsed three times with detection buffer (0.1 M Tris- $\mathrm{HCl} \mathrm{pH} 9.5,0.1 \mathrm{M} \mathrm{NaCl}, 50$ $\mathrm{mM} \mathrm{MgCl}_{2}$ ), and then covered with detection buffer containing $0.18 \mathrm{mg} / \mathrm{ml} \mathrm{BCIP}$ and $0.34 \mathrm{mg} / \mathrm{ml} \mathrm{NBT}$. The chromogenic reaction was carried out at $4^{\circ} \mathrm{C}$ for $16 \mathrm{~h}$. 
Finally slides were washed with $1 \times$ TE buffer, mounted with coverslips and photographed.

In order to synthesize the RNA probe, the 3' UTR of the construct introduced in mice was subcloned using the following primers:

5'ACTGACGAATTCCCCGGGGGATCCAGATCT TATT3' and

\section{5' ACTGACCTCGAGCCAGACATGATAAGATA CATTGATGAG 3'}

\section{Semi-quantitative PCR}

Skin samples from wild type and TRAIL transgenic mice were placed in $1 \mathrm{ml}$ TriZol and homogenized using an TissueRuptor. RNA was extracted according to the manufacturer's protocol. A DNase treatment was performed, followed by reverse transcription. The cDNAs obtained were analyzed by PCR, using the following primers, 5' GATCCTGAGAACTTCAGG 3' and 5' CTGCTTC ATCTCGTTGGTGA 3', which are specific for the transgene.

\section{Immunoblotting}

Skin samples from wild type and TRAIL transgenic mice were disrupted in liquid nitrogen using a pestle and a mortar. The resulting powder was homogenized in RIPA buffer (1\% NP 40, 0.5\% Sodium-deoxycholate, 0.1\% SDS in PBS) containing proetase inhibitors. Western blotting was performed according to standard protocols. AntiTRAIL (R\&D systems), anti-phospho-GSK3 $\beta$ (Ser9) (Cell signaling), anti- $\beta$ catenin (Upstate) and anti-Actin (Santa Cruz) antibodies were used. Secondary reagent used was horseradish peroxidase-coupled donkey antigoat, goat anti-rabbit or goat anti-mouse antibodies (Santa Cruz).

\section{Histological analysis}

Tumors were excised 35 weeks after DMBA/TPA application, fixed in $4 \%$ formaldehyde and embedded in paraffin. Sections of $5 \mu \mathrm{m}$ were made using a microtome and stained with hematoxilin and eosin according to standard protocols. Pictures were taken using a Leica microscope.

\section{Immunofluorescence}

Cryosections of lesions were rehydrated in PBS and fixed for $5 \mathrm{~min}$ at room temperature in $4 \%$ paraformaldehyde. After two washes in PBS 1X, tween 20 0.1\%, the sections were saturated for $1 \mathrm{~h}$ in Normal Goat Serum (NGS) 5\%, PBS 1X, tween $200.1 \%$ at room temperature and then incubated with primary antibodies overnight at $4^{\circ} \mathrm{C}$. Keratin 1 antibody (Covance Dabco) was diluted at $1 / 500^{\mathrm{e}}$ and $\alpha 6$-integrin antibody (BD Pharmingen) was diluted at $1 / 200^{\mathrm{e}}$. Sections were than incubated for $1 \mathrm{~h}$ at room temperature with alexa 488 conjugated Donkey
anti-Rabbit and Cy3 conjugated Donkey anti-Rat antibodies diluted at $1 / 400^{\mathrm{e}}$, washed and counterstained with Hoechst.

\section{Immunohistochemistry}

Paraffin sections of skin were deparaffinated in histosol and rehydrated. Antigen retrieval was performed in $10 \mathrm{mM}$ sodium citrate $\mathrm{pH} 6.0$ at $95^{\circ} \mathrm{C}$ for $10 \mathrm{~min}$. Endogenous peroxidase activity was blocked by incubation in $1 \% \mathrm{H}_{2} \mathrm{O}_{2}$ for $5 \mathrm{~min}$. After $1 \mathrm{H}$ of blocking, the sections were incubated over-night at $4{ }^{\circ} \mathrm{C}$ with $\mathrm{Ki} 67$ antibody (1:1000; Tebu-Bio), in humidified chamber. The slides were then washed and incubated with biotin-linked secondary antibody, followed by the ABC elite reagent (Vector). The AEC reagent (Vector) was used as a substrate prior to counterstaining with hematoxilin and mounting.

\section{Results}

Given the potential ability of TRAIL to induce apoptosis of tumor cells, while sparing normal cells, we decided to assess whether specific TRAIL expression in the skin could prevent tumor formation following a chemical carcinogenesis. To accomplish this, we engineered mice expressing mouse TRAIL cDNA under the control of the human keratin 14 promoter (Figure 1A). It has been previously established that such constructs express the transgene specifically in the basal cell layer of the epidermis $[30,31]$. One mouse line was obtained in the C57BL/6 background, and tested for TRAIL expression

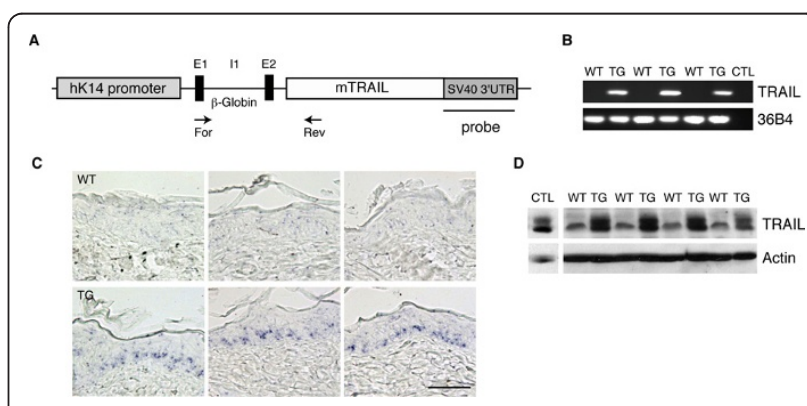

Figure 1 TRAIL expression in the skin driven by the human keratin 14 promoter. (A) Diagram of the construct introduced into ES cells. Between the mouse TRAIL CDNA and the human keratin 14 promoter, one $\beta$-globin intron and small parts of exon 1 and exon 2 were placed. The $3^{\prime}$ UTR of SV40 was added at the end the TRAIL cDNA. The primers used for RNA expression analysis and the probe used for in situ hybridization are indicated on the scheme. (B) RNA was extracted from skin of wild type and transgenic animals and after reverse-transcription, semi-quantitative PCR was performed using primers specific for the transgene. 36B4 was used as a positive control. (C) RNA expression was also evaluated by in situ hybridization, using a probe specific for the transgene. Blue staining shows TRAIL expression in the basal cell layer of epidermis of transgenic animals. Bar, $100 \mu \mathrm{m}$. (D) Western blot analysis of protein extracts from wild-type and transgenic mice using an anti-TRAIL antibody and actin antibody as a loading control. 
in the skin. Both at the RNA and protein levels approximately 5-fold higher TRAIL expression was found in the skin of transgenic animals than in wild-type animals (Figure 1B and 1D). Moreover, in situ hybridization using a probe specific for the transgene confirmed the restricted expression of the transgene in the basal cell layer of the epidermis (Figure 1C). These mice were thus considered valid to test the effect of TRAIL overexpression on chemical carcinogenesis relative to their non-transgenic littermates.

In order to compare the tumor development in wild-type and TRAIL-expressing mice, we proceeded to a DMBA/ TPA two-stage chemical carcinogenesis protocol, which consists of a single application of DMBA, followed by multiple applications of TPA for a 35 weeks period of time. While DMBA application corresponds to the initiation step of the tumor development process by inducing activating mutations of Ha-Ras oncogene [32,33], TPA application corresponds to the promotion step by inducing a clonal expansion of the initiated cells to form a benign tumor [34], which can eventually progress to a malignant carcinoma.

We first examined the skin structure of wild type and transgenic mice after a short-term treatment of DMBA/ TPA, corresponding to a single application of DMBA followed by four applications of TPA. The epidermal thickening normally observed in wild-type animals after TPA treatment was not affected in TRAIL expressing mice (Figure 2A and 2B), suggesting that TRAIL expression does not impair the proliferation rate induced by TPA

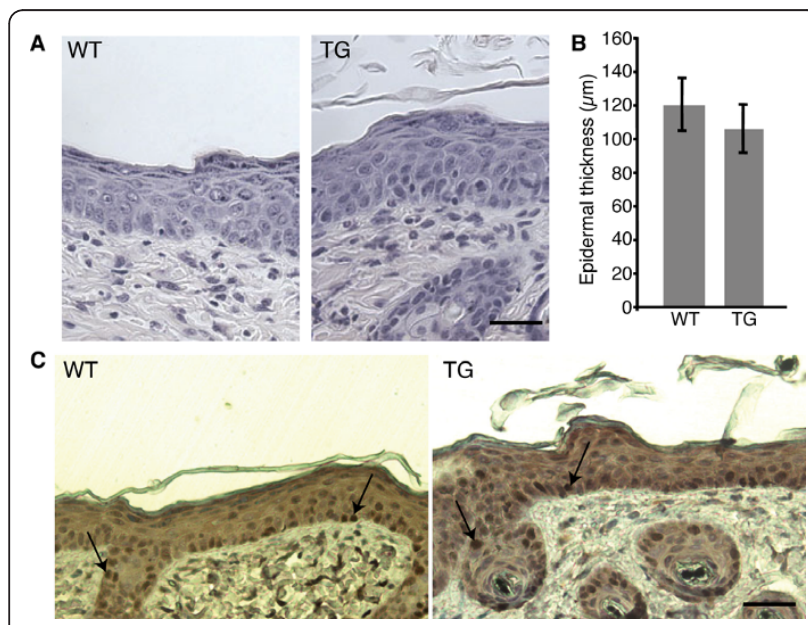

Figure 2 TRAIL expression does not affect the proliferation rate induced by a short DMBA/TPA treatment. Groups of four control and TRAIL transgenic animals were treated with DMBA/TPA for three weeks (one DMBA and four TPA applications). (A) Analysis of cell proliferation on histological skin sections with hematoxilin \& eosin staining. Bar, $50 \mu \mathrm{m}$. (B) Quantification of epidermal thickness in micrometers, evaluated by measurements of 15 fields per animal. (C) Cell proliferation evaluated by Ki67 staining on skin sections. Bar, $50 \mu \mathrm{m}$. application. Ki67 staining of skin sections from treated wild type and transgenic mice further confirmed this notion (Figure 2C). We then started the full DMBA/TPA treatment (as illustrated in Figure 3A) on cohorts of 21 wild type and 21 transgenic mice. Whereas control animals started to develop lesions after 8 weeks of treatment, the onset of lesion formation was shortly delayed in TRAIL expressing mice, with the first appearance after 11 weeks (Figure 3B). Apart from that difference, the general tumor incidence rate was not significantly affected in TRAIL expressing mice compared to control mice, as independently of the genotype, approximately $90 \%$ of the animals developed lesions before the $30^{\text {th }}$ week of the treatment (Figure 3B). However, the most striking difference concerned the number of lesions observed in TRAIL expressing mice compared to control mice. Indeed, whereas the cumulative number of lesions in control animals was around 50, it was only about 30 in TRAIL transgenic mice at the end of the experiment (Figure 3C). When analyzing the number of lesions per animal, we noticed that whereas transgenic mice never presented more then three lesions, wild-type mice could display up to six lesions (Figure 3D). However, the size of the lesions was not significantly different in the wild type compared to transgenic animals (data not shown).

At the end of the treatment, the lesions were excised for histological analysis. Surprisingly, none of the lesions

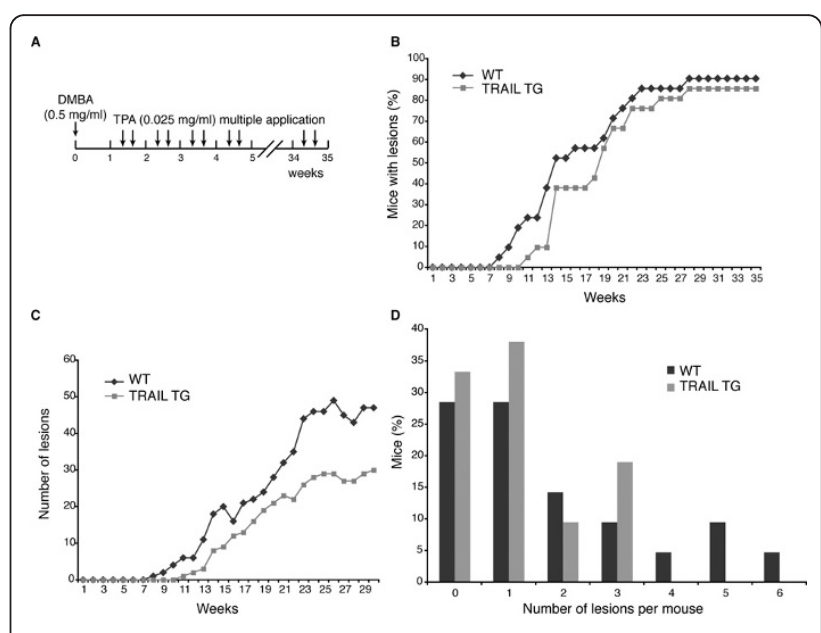

Figure 3 DMBA/TPA-induced tumor formation is delayed and lower number of tumors is formed in TRAIL expressing mice compared to controls. (A) DMBA and TPA treatment procedure. Single topical application of DMBA $(0.5 \mathrm{mg} / \mathrm{ml})$ was performed, followed by multiple applications of TPA $(0.025 \mathrm{mg} / \mathrm{ml})$, twice a week for 35 weeks. (B) Tumor incidence; percentage of mice with at least one tumor depending on time. (C) Total number of tumors in wild-type versus transgenic animals. A significant difference exists during the whole period of time of the experiment except at week 16 and week 19, as determined by Poisson distribution (D) Number of tumors per mouse; the percentage of wild-type and transgenic mice with different number of tumors was evaluated. 
analyzed were transformed into carcinomas. Among the benign lesions we could distinguish three different categories: hamartomas, trichofolliculomas and papillomas (Figure 4A). Whereas the two first types of lesions are benign and never transform into carcinomas, the last represents a bona fide preneoplastic lesion, as it can eventually evolve into a carcinoma. This classification was confirmed by immunohistochemical analysis for keratin 1 (K1) and $\alpha 6$-integrin expression, as it is well established that $\mathrm{K} 1$ expression is lost whereas $\alpha 6$-integrin expression is increased in lesions with high risk of transformation [35], which corresponds to our classification (Figure 4B). When quantifying the proportion of the different categories of lesions, we observed that wild type animals presented half benign and half preneoplasic lesions (Figure 4C). In contrast, less than $20 \%$ of the lesions observed in TRAIL transgenics were preneoplastic, most of them were hamartomas and trichofolliculoma (Figure 4C).

Activation of $\mathrm{Wnt} / \beta$-catenin/Tcf signaling has been reported in non-melanocytic skin tumors induced by the two-stage carcinogenesis protocol used in the present study [36]. We therefore analyzed the expression levels

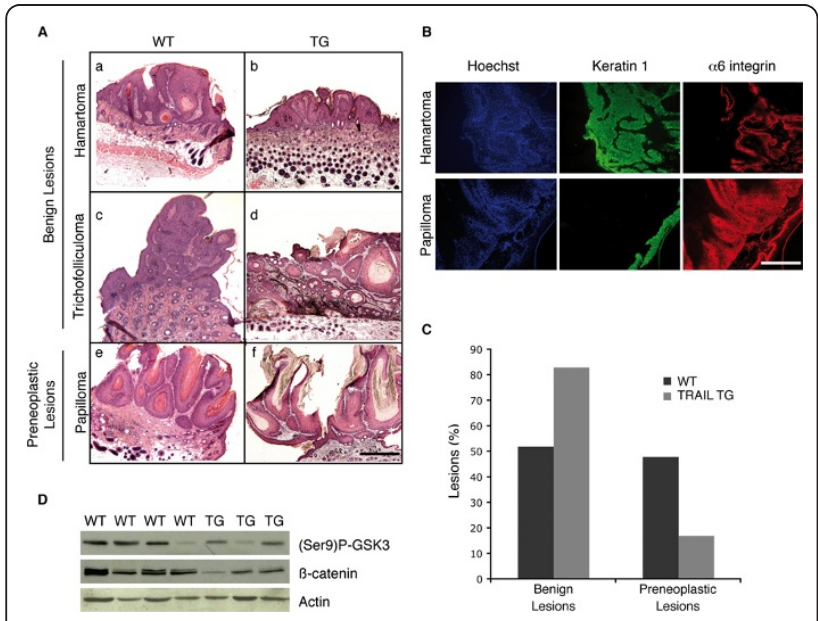

Figure 4 TRAIL expressing mice develop less preneoplastic lesions compared to wild-type animals. (A) Representative images of the histologic structure of the lesions provoqued by the treatment. DMBA/TPA treated mice develop three different types of lesions: hamartomas, trichofolliculomas and papillomas, the two first being benign whereas the last one is a preneoplastic lesion. Bar, $400 \mu \mathrm{m}$. (B) Representative immunofluorescence images of hamartoma and papilloma lesions stained with Keratin 1 and $\alpha 6$ integrin. Bar, $100 \mu \mathrm{m}$. (C) Percentage of benign versus preneoplastic lesions in TRAIL transgenic mice compared to wild-type mice. The difference observed between wild-type and TRAIL transgenic lesions is highly significant $(P<0.0001)$, as determined by Fisher's exact test. (D) Western blot analysis of wild type and transgenic tumor samples using antibodies against two transformation markers, inactivated GSK3 phosphorylated at Ser9 and $\beta$-catenin. Actin is used as a loading control. of $\beta$-catenin in several tumors of both wild type and transgenic mice (Figure 4D). Most notably, $\beta$-catenin levels were lower in all the tumors extracted from TRAIL-expressing animals relative to tumors of the wild-type counterparts. Given the link between GSK3 and Wnt/ $\beta$-catenin/Tcf signaling $[37,38]$, we monitored the functional status of GSK3 $\beta$ in the two classes of tumors. Interestingly, the inactive form of GSK3$\beta$, which is phosphorylated at serin 9 (GSK3 $\beta$ pSer9), exhibited a significantly reduced expression level in transgenic lesions compared to the wild type animals (Figure 4D), suggesting that in the TRAIL overexpressing mice the development of benign lesions with active GSK3 $\beta$ and, possibly as a consequence, increased levels of $\beta$-catenin is disfavored. Altogether, these observations support the notion that TRAIL expression in the skin of mice partly protects them from chemical carcinogenesis already at the early steps when benign tumors form and progress.

\section{Discussion}

In this study, we have evaluated the effect of constitutive TRAIL overexpression in a specific organ and its implication in tumor prevention following chemical carcinogenesis. Transgenic mice specifically overexpressing TRAIL in the skin were viable and were phenotypically indistinguishable from their wild type littermates. Their skin architecture was normal (data not shown); therefore, constitutive expression of TRAIL in the basal cell layer of the epidermis at the levels observed in the transgenic animals is not toxic and does not interfere with the normal development and/or homeostasis of skin.

Several reports have demonstrated that TRAIL could induce proliferation through either the ERK or the NF $\kappa \mathrm{B}$ pathway $[27,39,40]$. In our model, we could not detect any effect on proliferation nor any activation of either ERK or $\mathrm{NF} \kappa \mathrm{B}$ when we performed either the short DMBA/TPA treatment or the complete treatment on the skin of TRAIL transgenic mice compared to wild-type mice (Figure 2 and data not shown). So in this model of transgenic mice, even if TRAIL overexpression does not induce apoptosis of the normal epithelial cells, it doesn't lead to an increase in proliferation of the cells either. It has previously been observed that in certain inflammatory conditions, such as rheumatoid arthritis, TRAIL displayed a bimodal action on the proliferation of synovial fibroblasts [28]. The chemical carcinogenesis protocol obviously induces inflammatory skin processes. The fact that despite an induction of inflammation we did not observe any significant effect of proliferation indicates that in the mouse in vivo inflammation per se does not result in a proliferative response towards excess TRAIL. It is possible that the effect observed in synoviocytes is cell type-specific or that, alternatively, it requires TRAIL doses, which were not reached in the transgenic animals. 
The fact that none of the lesions formed following the DMBA/TPA treatment progressed into a squamous cell carcinoma (Figure 4A) was most probably due to the genetic background of the mice in which we performed the experiment. Indeed, mice from C57BL/6 background have previously been reported to be more resistant to tumor development and particularly to skin carcinogenesis, in contrast to mice having a DBA/2 genetic background which present a higher rate of tumors formation when subjected to the same protocol [41]. However, this resistance of benign tumors to progress to malignant lesions provided us with the opportunity to study the effect of high endogenous levels of TRAIL in skin on the early step of the skin tumorigenesis. Indeed, it is generally accepted from in vitro experiments and results obtained with xenografts in vivo that only fully transformed cells are sensitive towards the apoptogenic action of the TRAIL signaling pathways. This selectivity has been functionally linked to the expression of oncogenes such as Ras and Myc [42-46] but no coherent general mechanism has evolved that would account for the observed tumor-selectivity in a variety of experimental systems [discussed by [25]]. In some studies an effect of TRAIL on premalignant cells has been observed, but this effect depended on the combination with other agents, such as all-trans-retinyl acetate. Most notably, all-transretinyl acetate sensitized premalignant adenoma cells of APC-deficient mice to TRAIL-induced apoptosis, thus establishing a paradigm for chemoprevention of colon cancer by retinoic acid-TRAIL combination therapy [47].

In our model however, increased endogenous levels of TRAIL alone were sufficient for pretransformed cells to induce a delay in the onset of the tumorigenesis and a statistically significant decrease in the number of these lesions in TRAIL transgenic animals, if compared to wild-type littermates (Figure $4 \mathrm{C}$ ). It will be interesting to test the effect of other drugs, such as all-trans-retinyl acetate or even standard chemotherapy for synergistic effects with high TRAIL levels. If confirmed using other models of transgenic mice and other models of tumorigenesis, this observation that TRAIL expression in a particular cell type can play a protective role at the earliest stage of tumorigenesis is of great interest. Indeed, the present model can be readily adapted to study the effects of high levels of endogenous TRAIL in a particular organ alone or in combination with TRAIL "sensitizers" [48-50] or other cancer therapeutics. Given the ongoing efforts to develop increasingly improved mouse models mimicking particular human tumors, such as the widely used MMTV-erbB2 transgenics for breast cancer, the present mouse model constitutes a versatile preclinical model to assess possible synergies between TRAILbased therapeutics, such as recombinant TRAIL derivatives, TRAIL mimics or agonistic TRAIL receptor antibodies, and other cancer therapeutics in a organ and tumor type-specific manner.

\section{List of abbreviations}

TRAIL: tumor necrosis factor-related apoptosis-inducing ligand; FADD: FASassociated protein with death domain; DISC: death-inducing signaling complex; DMBA: 7,12-dimethyl-benz-anthracene; TPA: 12-0tetradecanoylphorbol-13-acetate; SCC: squamous cell carcinoma.

\section{Acknowledgements}

This work was supported by the European Commission (contract LSHC-CT2005-518417 'EPITRON', HEALTH-F4-2007-200767 'Apo-Sys') and Ligue contre le Cancer (équipe labellisée). V.K. is the recipient of a fellowship from La Ligue Contre de Cancer.

We thank Jean-Marie Garnier (vector construction) and Marie-Christine Birling (transgenesis) for help in the generation of transgenic TRAIL mice, Lydie Venteo and Muriel Philipps for their help for the in situ hybridization and Danilo Ceschin for statistical analyzes. We are grateful to Catherine Huck and Judith Vallet for excellent technical assistance.

\section{Authors' contributions}

VK participated to the conception of the study, carried out the experimental design, performed the experiments and drafted the manuscript. SM analyzed the histological sections and performed the classification of the lesions. She read and approved the manuscript. HG conceived the study and participated in its design, and helped to draft the manuscript. All authors read and approved the final manuscript.

\section{Conflict of interests}

The authors declare that they have no competing interests.

Received: 3 January 2011 Accepted: 4 April 2011 Published: 4 April 2011

\section{References}

1. Ashkenazi A, Holland P, Eckhardt SG: Ligand-based targeting of apoptosis in cancer: the potential of recombinant human apoptosis ligand 2/ Tumor necrosis factor-related apoptosis-inducing ligand (rhApo2L/ TRAIL). J Clin Oncol 2008, 26:3621-3630.

2. Wiley SR, Schooley K, Smolak PJ, Din WS, Huang CP, Nicholl JK, Sutherland GR, Smith TD, Rauch C, Smith CA, et al: Identification and characterization of a new member of the TNF family that induces apoptosis. Immunity 1995, 3:673-682.

3. MacFarlane M, Ahmad M, Srinivasula SM, Fernandes-Alnemri T, Cohen GM, Alnemri ES: Identification and molecular cloning of two novel receptors for the cytotoxic ligand TRAIL. J Biol Chem 1997, 272:25417-25420.

4. Walczak H, Degli-Esposti MA, Johnson RS, Smolak PJ, Waugh JY, Boiani N, Timour MS, Gerhart MJ, Schooley KA, Smith CA, et al: TRAIL-R2: a novel apoptosis-mediating receptor for TRAIL. Embo J 1997, 16:5386-5397.

5. Ashkenazi A: Targeting death and decoy receptors of the tumournecrosis factor superfamily. Nat Rev Cancer 2002, 2:420-430.

6. Schneider P, Olson D, Tardivel A, Browning B, Lugovskoy A, Gong D, Dobles M, Hertig S, Hofmann K, Van Vlijmen H, et al: Identification of a new murine tumor necrosis factor receptor locus that contains two novel murine receptors for tumor necrosis factor-related apoptosisinducing ligand (TRAIL). J Biol Chem 2003, 278:5444-5454.

7. Wu GS, Burns TF, Zhan Y, Alnemri ES, El-Deiry WS: Molecular cloning and functional analysis of the mouse homologue of the KILLER/DR5 tumor necrosis factor-related apoptosis-inducing ligand (TRAIL) death receptor. Cancer Res 1999, 59:2770-2775.

8. Johnstone RW, Frew AJ, Smyth MJ: The TRAIL apoptotic pathway in cancer onset, progression and therapy. Nat Rev Cancer 2008, 8:782-798.

9. Takeda K, Smyth MJ, Cretney E, Hayakawa Y, Yamaguchi N, Yagita H, Okumura K: Involvement of tumor necrosis factor-related apoptosisinducing ligand in NK cell-mediated and IFN-gamma-dependent suppression of subcutaneous tumor growth. Cell Immunol 2001, 214:194-200.

10. Takeda K, Smyth MJ, Cretney E, Hayakawa Y, Kayagaki N, Yagita H, Okumura K: Critical role for tumor necrosis factor-related apoptosis- 
inducing ligand in immune surveillance against tumor development. $J$ Exp Med 2002, 195:161-169.

11. Cretney E, Takeda K, Yagita H, Glaccum M, Peschon JJ, Smyth MJ: Increased susceptibility to tumor initiation and metastasis in TNF-related apoptosis-inducing ligand-deficient mice. J Immunol 2002, 168:1356-1361.

12. Zerafa N, Westwood JA, Cretney E, Mitchell S, Waring P, lezzi M, Smyth MJ: Cutting edge: TRAIL deficiency accelerates hematological malignancies. $J$ Immunol 2005, 175:5586-5590.

13. Grosse-Wilde A, Voloshanenko O, Bailey SL, Longton GM, Schaefer U, Csernok Al, Schutz G, Greiner EF, Kemp CJ, Walczak H: TRAIL-R deficiency in mice enhances lymph node metastasis without affecting primary tumor development. J Clin Invest 2008, 118:100-110.

14. Finnberg N, Klein-Szanto AJ, El-Deiry WS: TRAIL-R deficiency in mice promotes susceptibility to chronic inflammation and tumorigenesis. $J$ Clin Invest 2008, 118:111-123.

15. Takeda K, Yamaguchi N, Akiba H, Kojima Y, Hayakawa Y, Tanner JE, Sayers TJ, Seki N, Okumura K, Yagita H, Smyth MJ: Induction of tumorspecific T cell immunity by anti-DR5 antibody therapy. J Exp Med 2004, 199:437-448

16. Smyth MJ, Cretney E, Takeda K, Wiltrout RH, Sedger LM, Kayagaki N, Yagita H, Okumura K: Tumor necrosis factor-related apoptosis-inducing ligand (TRAIL) contributes to interferon gamma-dependent natural killer cell protection from tumor metastasis. J Exp Med 2001, 193:661-670.

17. Walczak H, Miller RE, Ariail K, Gliniak B, Griffith TS, Kubin M, Chin W, Jones J, Woodward A, Le T, et al: Tumoricidal activity of tumor necrosis factorrelated apoptosis-inducing ligand in vivo. Nat Med 1999, 5:157-163.

18. Ashkenazi A, Pai RC, Fong S, Leung S, Lawrence DA, Marsters SA, Blackie C, Chang L, McMurtrey AE, Hebert A, et al: Safety and antitumor activity of recombinant soluble Apo2 ligand. J Clin Invest 1999, 104:155-162.

19. Georgakis GV, Li Y, Humphreys R, Andreeff M, O'Brien S, Younes M, Carbone A, Albert V, Younes A: Activity of selective fully human agonistic antibodies to the TRAIL death receptors TRAIL-R1 and TRAIL-R2 in primary and cultured lymphoma cells: induction of apoptosis and enhancement of doxorubicin- and bortezomib-induced cell death. $\mathrm{Br} J$ Haematol 2005, 130:501-510.

20. Motoki K, Mori E, Matsumoto A, Thomas M, Tomura T, Humphreys R, Albert V, Muto M, Yoshida H, Aoki M, et al: Enhanced apoptosis and tumor regression induced by a direct agonist antibody to tumor necrosis factor-related apoptosis-inducing ligand receptor 2. Clin Cancer Res 2005, 11:3126-3135.

21. Pukac L, Kanakaraj P, Humphreys R, Alderson R, Bloom M, Sung C, Riccobene T, Johnson R, Fiscella M, Mahoney A, et al: HGS-ETR1, a fully human TRAlL-receptor 1 monoclonal antibody, induces cell death in multiple tumour types in vitro and in vivo. Br J Cancer 2005, 92:1430-1441.

22. Mitsiades CS, Treon SP, Mitsiades N, Shima Y, Richardson P, Schlossman R, Hideshima T, Anderson KC: TRAIL/Apo2L ligand selectively induces apoptosis and overcomes drug resistance in multiple myeloma: therapeutic applications. Blood 2001, 98:795-804.

23. Naka T, Sugamura K, Hylander BL, Widmer MB, Rustum YM, Repasky EA: Effects of tumor necrosis factor-related apoptosis-inducing ligand alone and in combination with chemotherapeutic agents on patients' colon tumors grown in SCID mice. Cancer Res 2002, 62:5800-5806.

24. Gonzalvez F, Ashkenazi A: New insights into apoptosis signaling by Apo2L/TRAIL. Oncogene 2010, 29:4752-4765.

25. Pavet V, Portal MM, Moulin JC, Herbrecht R, Gronemeyer H: Towards novel paradigms for cancer therapy. Oncogene 2011, 30:1-20.

26. Pavet V, Beyrath J, Pardin C, Morizot A, Lechner MC, Briand JP, Wendland M, Maison W, Fournel S, Micheau O, et al: Multivalent DR5 peptides activate the TRAIL death pathway and exert tumoricidal activity. Cancer Res 2010, 70:1101-1110.

27. Ehrhardt H, Fulda S, Schmid I, Hiscott J, Debatin KM, Jeremias I: TRAIL induced survival and proliferation in cancer cells resistant towards TRAILinduced apoptosis mediated by NF-kappaB. Oncogene 2003, 22:3842-3852.

28. Audo R, Combe B, Coulet B, Morel J, Hahne M: The pleiotropic effect of TRAIL on tumor-like synovial fibroblasts from rheumatoid arthritis patients is mediated by caspases. Cell Death Differ 2009, 16:1227-1237.

29. Kemp CJ: Multistep skin cancer in mice as a model to study the evolution of cancer cells. Semin Cancer Biol 2005, 15:460-473.
30. Li M, Indra AK, Warot X, Brocard J, Messaddeq N, Kato S, Metzger D, Chambon P: Skin abnormalities generated by temporally controlled RXRalpha mutations in mouse epidermis. Nature 2000, 407:633-636.

31. Vassar R, Rosenberg M, Ross S, Tyner A, Fuchs E: Tissue-specific and differentiation-specific expression of a human K14 keratin gene in transgenic mice. Proc Natl Acad Sci USA 1989, 86:1563-1567.

32. Balmain A, Ramsden M, Bowden GT, Smith J: Activation of the mouse cellular Harvey-ras gene in chemically induced benign skin papillomas. Nature 1984, 307:658-660.

33. Quintanilla M, Brown K, Ramsden M, Balmain A: Carcinogen-specific mutation and amplification of Ha-ras during mouse skin carcinogenesis. Nature 1986, 322:78-80.

34. Karen J, Wang Y, Javaherian A, Vaccariello M, Fusenig NE, Garlick JA: 12-Otetradecanoylphorbol-13-acetate induces clonal expansion of potentially malignant keratinocytes in a tissue model of early neoplastic progression. Cancer Res 1999, 59:474-481.

35. Tennenbaum T, Weiner AK, Belanger AJ, Glick AB, Hennings H, Yuspa SH: The suprabasal expression of alpha 6 beta 4 integrin is associated with a high risk for malignant progression in mouse skin carcinogenesis. Cancer Res 1993, 53:4803-4810.

36. Bhatia N, Spiegelman VS: Activation of Wnt/beta-catenin/Tcf signaling in mouse skin carcinogenesis. Mol Carcinog 2005, 42:213-221.

37. Wu D, Pan W: GSK3: a multifaceted kinase in Wnt signaling. Trends Biochem Sci 2010, 35:161-168.

38. MacDonald BT, Tamai K, He X: Wnt/beta-catenin signaling: components, mechanisms, and diseases. Dev Cell 2009, 17:9-26.

39. Belyanskaya LL, Ziogas A, Hopkins-Donaldson S, Kurtz S, Simon HU, Stahel R, Zangemeister-Wittke U: TRAIL-induced survival and proliferation of SCLC cells is mediated by ERK and dependent on TRAIL-R2/DR5 expression in the absence of caspase-8. Lung Cancer 2008, 60:355-365.

40. Secchiero P, Gonelli A, Carnevale E, Milani D, Pandolfi A, Zella D, Zauli G: TRAIL promotes the survival and proliferation of primary human vascular endothelial cells by activating the Akt and ERK pathways. Circulation 2003, 107:2250-2256.

41. Feith DJ, Shantz LM, Shoop PL, Keefer KA, Prakashagowda C, Pegg AE: Mouse skin chemical carcinogenesis is inhibited by antizyme in promotion-sensitive and promotion-resistant genetic backgrounds. Mol Carcinog 2007, 46:453-465.

42. Drosopoulos KG, Roberts ML, Cermak L, Sasazuki T, Shirasawa S, Andera L, Pintzas A: Transformation by oncogenic RAS sensitizes human colon cells to TRAIL-induced apoptosis by up-regulating death receptor 4 and death receptor 5 through a MEK-dependent pathway. J Biol Chem 2005, 280:22856-22867.

43. Nesterov A, Nikrad M, Johnson T, Kraft AS: Oncogenic Ras sensitizes normal human cells to tumor necrosis factor-alpha-related apoptosisinducing ligand-induced apoptosis. Cancer Res 2004, 64:3922-3927.

44. Ricci MS, Jin Z, Dews M, Yu D, Thomas-Tikhonenko A, Dicker DT, ElDeiry WS: Direct repression of FLIP expression by c-myc is a major determinant of TRAIL sensitivity. Mol Cell Biol 2004, 24:8541-8555.

45. Ricci MS, Kim SH, Ogi K, Plastaras JP, Ling J, Wang W, Jin Z, Liu YY, Dicker DT, Chiao PJ, et al: Reduction of TRAIL-induced Mcl-1 and CIAP2 by c-Myc or sorafenib sensitizes resistant human cancer cells to TRAILinduced death. Cancer Cell 2007, 12:66-80

46. Wang Y, Engels IH, Knee DA, Nasoff M, Deveraux QL, Quon KC: Synthetic lethal targeting of MYC by activation of the DR5 death receptor pathway. Cancer Cell 2004, 5:501-512.

47. Zhang L, Ren X, Alt E, Bai X, Huang S, Xu Z, Lynch PM, Moyer MP, Wen XF, Wu X: Chemoprevention of colorectal cancer by targeting APC-deficient cells for apoptosis. Nature 2010, 464:1058-1061.

48. Jacquemin G, Shirley S, Micheau O: Combining naturally occurring polyphenols with TNF-related apoptosis-inducing ligand: a promising approach to kill resistant cancer cells? Cell Mol Life Sci 2010, 67:3115-3130.

49. Fulda S: Modulation of TRAIL-induced apoptosis by HDAC inhibitors. Curr Cancer Drug Targets 2008, 8:132-140.

50. Koschny R, Walczak H, Ganten TM: The promise of TRAIL-potential and risks of a novel anticancer therapy. J Mol Med 2007, 85:923-935.

doi:10.1186/1476-4598-10-34

Cite this article as: Kedinger et al:: Targeted expression of tumor necrosis factor-related apoptosis-inducing ligand TRAIL in skin protects mice against chemical carcinogenesis. Molecular Cancer 2011 10:34. 